\title{
GAYA KEPEMIMPINAN KEPALA SEKOLAH BERAGAMA KRISTEN PADA SEKOLAH SEKULER
}

\author{
Alki Firton Tambunan'), Abai Manupak Tambunan ${ }^{2 *}$ \\ ${ }^{1}$ SMA Negeri 2 Lumajang \\ ${ }^{2}$ Manajemen Pendidikan Kristen, IAKN Tarutung
}

\begin{abstract}
This research describes how leadership style of principal of a Christian in a seculer Schooll and It is explained that the direct or indirect off leadership to implement values of biblical and to get results that are authentic and profound, the research executed with the analysis of the qualitative and case study approach with the role of the researcher as the key instrument. Here found the conclusion or result that leadership style of school off principal affected the teachings of religion in him believe in the context of the head of school has an opportunity to introduce of christian religion to the surrounding.
\end{abstract}

Keywords: religion, leadership style, principal

\begin{abstract}
Abstrak
Penelitian ini mendeskripsikan bagaimana gaya kepempimpinan seorang kepala sekolah beragama kristen pada sekolah sekuler, gambaran pada kepemimpinan tersebut secara langsung maupun tidak langsung mengimplementasikan beberapa nilai-nilai Alkitabiah. Mendapatkan hasil yang otentik dan mendalam, penelitian ini dilaksanakan dengan menggunakan analisis kualitatif dengan pendekatan studi kasus dengan peran peneliti sebagai instrumen kunci. Ditemukan kesimpulan bahwa gaya kepemimpinan seorang kepala sekolah turut dipengaruhi ajaran agama yang dianutnya, dalam kontek tersebut kepala sekolah berpeluang memperkenalkan ajaran kristen yang dianutnya pada orangorang disekitar tempat kerjanya.
\end{abstract}

Katakunci : agama, gaya kepemimpinan, kepala sekolah

\section{PENDAHULUAN}

Indonesia adalah surga bagi kemajemukan, ragam suku bangsa, ragam agama, ragam kearifan lokal yang dimiliki dari Sabang sampai Marauke dari Miangas sampai pulau Rote adalah kekayaan yang tidak mungkin sama seperti yang dimiliki negara lain. kekayaan dan kelimpahan tersebut berjalan seirama dengan keadilan yang diberikan oleh pemangkuh kepercayaan rakyat, diimbangi adanya perlakuan yang sama tanpa diskriminasi walau berasal dari komunitas manapun, hal kearifan tersebut dapat

14 | Korespondensi mengenai artikel dapat dilakukan kepada:

Abai Manupak Tambunan, Institut Agama Kristen Negeri Tarutung-Desa Silangkitang-Pagar Batu

Email: abai.tambunan@yahoo.com 
diwujudkan karena pada dasarnya setiap diri manusia membawa perbedaan yang multikulturalisme jika dilihat pada nilai dan prinsifnya semua beresensi pada sikap yang diharapkan supaya terbentuk interaksi saling menghargai dan menghormati antar sesama manusia (Raharjo jati, 2014).

Dengan fenomena yang ada di Indonesia semisal dari keadaan alam serta kekayaan budaya yang dimiliki seharusnya diungkapkan ucapan syukur oleh seluruh anak bangsa yang perlu disampaikan disetiap kesempatan dan disituasi apapun, jika diamati memang bukan suatu yang mudah untuk melakukan tindakan patriot tersebut, dalam ruang lingkup sosial walaupun dibayangi oleh fakta akan datangnya pengaruh buruk dari dampak globalisasi, sependapat dengan Murdiono (2014) yang berkata bahwa informasi akan datang silih berganti memiilki dampak terhadap kehidupan warga negara diseluruh dunia, ideologi, gaya hidup, dan keyakinan yang berkembang disuatu negara dapat mempengaruhi kebiasaan dan pola-pola kehidupan yang sudah mapan pada negara lain, berdasarkan informasi tersebut dapat ditarik suatu nilai positif yang dirasakan sebagai penguat bahwa terhadap fenomena tersebut yang mana pemerintah menjadi garda terdepan yang mengayomi siapapun dan menjamin hak-hak setiap warga negara apapun kadaan dan perubahan yang akan terjadi di dunia berdasarkan amanat undang-undang, dewasa ini prakteknya diharapkan dapat dirasakan dalam aktifitas pekerjaan, kebebasan beragama, dan tindakan-tidakan sosial lainnya yang terukur. Jika merujuk dalam konteks ruang lingkup pekerjaan karena penelitian ini juga mengamati tersalurnya suatu kemerataan dan keadilan dalam memperoleh pekerjaan tanpa melihat status sosial baik di instansi pemerintah ataupun swasta, istilah menjamin tersebut maknanya adalah bahwa setiap individu berkesempatan untuk menjadi pemimpin dirinya sendiri dan orang lain, asalkan sesuai dengan kriteria dan kompetensi yang dimiliki dan dipersyaratkan, atas landasan tersebut memilih pemimpin sering kali disoroti dan diamati untuk dipahami bahwa tidak bisa dalam suatu tindakan mengambil keputusan dalam memilih pemimpin terkesan dengan pertimbangan matematis ataupun dengan rumus yang mutlak tetapi harus melihat dari passion calon pemimpin ( Usat, 2019).

Sudah tidak awam lagi didengar, jika membicarakan hak untuk memiliki jabatan dalam suatu pekerjaan patut dipahami dan dibanggakan masih banyak dalam prosesnya menjunjung tinggi nilai keadilan yang penekannya melarang siapapun memilih seorang

15| Gaya Kepemimpinan Kepala Sekolah Beragama Kristen ..., Alki; Abai

Jurnal Christian Humanioran | http://e-journal.iakntarutung.ac.id/index.php/humaniora 
pemimpin berdasarkan identitas pribadi atau golongan, dengan dasar keadilan tersebut, tidak sedikit ditemukan banyak pengikut Yesus dipercayakan menjadi pemimpin pada suatu lembaga ataupun instansi, berbicara mengenai hal kepemimpinan pada instansi, kepemimpinan di sekolah merupakan miniatur gambaran suksesnya keberhasilan pemerintah meningkatkan partisipatif masyarakat tanpa unsur-unsur diskriminatif, dewasa ini kehadiran seorang kepala sekolah yang memiliki perbedaan agama dengan warga di sekitar sekolah adalah nilai yang perlu diapresiasi karena menjunjung tinggi adab-adab kemajemukan, memang tidak menutup kemungkinan intrik dan konflik halnya seperti singa yang menantikan makanan, seperti itu juga ada kemungkinan kepemimpinan kepala sekolah tersebut akan goyang dan mengalami berbagai macam benturan dan hambatan oleh karena intrik dan konflik yang siap menghadang tersebut, tetapi dalam penelitian ini peneliti berusaha menyampingkan apapun stigma-stigma yang ada dan seberapa besar peluang-peluang yang mungkin terjadi, Peneliti hanya mengamati dan berusaha mengungkapkan, bagaimana gaya kepemimpinan seorang kepala sekolah yang beragama Kristen ketepatannya dipercayakan pada sekolah umum atau sekuler dan berusaha mengungkapkan dampak-dampak positif maupun negatif yang muncul kepermukaan dan peneliti juga mencoba menafsirkan hubungan yang terkait antara kekuasaan tersebut dengan pengabaran Injil dalam arti orang mengetahui dan memahami, bahkan mengenal Kekristenan itu apakah efektif diperoleh dan berasal dari seseorang yang tersirat pada wibawa kepemimpinannya, seorang pemimpin tidak mungkin bisa memberikan hal yang baik dan positif jikalau dia tidak menjalankan apa yang baik dan positif pula,berdasarkan ungkapan tersebut seorang pemimpin akan diamati dan direkam dalam benak pikiran orang lain, segala tingkah laku dan perbuatannya menjadi objek utama dalam pengabaran Injil melalui hidupnya. kembali berdasarkan penekanan hal tersebut, Peneliti menganggap bahwa penelitian ini penting dilakukan untuk mengukur sejauh mana seseorang pemimpin yang beragama Kristen mengaplikasikan nilai yang diajarkan dan dipelajari dalam hidupnya pada orang yang belum mengenal kehidupan istilah kehidupan yang dimaksud adalah keselamatan yang hakiki dari Yesus Kristus, memang dalam prakteknya seorang pemimpin tidak serta merta memiliki gaya kepemimpinan yang siknifikan berbeda dengan gaya 
kepemimpinan pada umumnya bahkan cenderung memiliki kesamaan satu dengan yang lain tetapi, realita apakah seorang pemimpin yang Juga memiliki kesamaan tersebut, dapat dipastikan membawa pola dan kebiasaan yang sama juga, yang akan mempengaruhi orang lain baik secara langsung ataupun tidak langsung, dasar tersebut memberi sinyal kepada peneliti untuk melakukan penelitian ini dengan upaya mengungkapkan kemungkinan tersebut. sehingga memastikan dan menjelaskan berdasarkan pengalaman yang terjadi disimpulkan dari gaya kepemimpinan seseorang.

\section{METODE PENELITIAN}

Penelitian ini merupakan penelitian kualitatif dengan pendekatan studi kasus, pengumpulan data dengan konsep triangulasi data yang didalamnya mengintegrasikan teknik wawancara, observasi, studi dokumen, wawancara dilakukan dengan beberapa informan yaitu kepala sekolah, guru, siswa, tenaga kependidikan, dan Stakeholder. Observasi dilakukan dengan cara ikut serta hadir beberapa kali dengan mengamati aktifitas dalam komunitas di sekolah, instrumen pengambilan data selain peneliti sebagai instrument kunci, juga menggunakan alat perekam serta kamera untuk mengambil fotofoto dalam wawancara dilakukan secara bebas, agar tidak terkesan formal dan kritis. Dengan demikian data diperoleh mengalir seperti yang diinginkan. Pertanyaan yang di ajukan berkisar tentang diri kepala sekolah Sekolah Dasar Umum baik gaya dan kompetensi yang dimilkinya, jawaban yang diperoleh dengan direkam maupun yang dicatat kemudian disederhanakan sesuai fokus penelitian dan analisis dengan rujukan teori-teori yang relevan. Observasi dilakukan dengan pengamatan di setiap kegiatan terstruktur atau tidak terstruktur dengan maksud menjalin keakraban sehingga objek dapat diajak berkomunikasi apa adanya tanpa ada rasa curiga. Laporan penelitian ini disusun dalam bentuk naratif untuk menjelaskan informasi yang diperoleh secara kualitatif.

\section{HASIL DAN PEMBAHASAN}

\section{Kepala Sekolah Berperan Sebagai Orang Tua Di Sekolah}

Kepala sekolah dalam tugasnya di sekolah, adalah seorang tenaga fungsional guru yang diamanatkan untuk memimpin suatu sekolah yang harapannya terjadi proses pembelajaran yang baik dan maksimal pada suatu sekolah sependapat dengan pendapat

17 | Gaya Kepemimpinan Kepala Sekolah Beragama Kristen ..., Alki; Abai

Jurnal Christian Humanioran | http://e-journal.iakntarutung.ac.id/index.php/humaniora 
dari Virgo dan Slameto ( 2018) yang berkata bahwa kepala sekolah bertanggung jawab akan manajemen pendidikan secara mikro yang secara langsung berkaitan dengan proses pembelajaran, kehadiran kepala sekolah juga diharapkan menjamin kondusifitas setiap interaksi disekolah, karena maju mundurnya situasi pendidikan serta tercapainya tujuan pendidikan berada di pundak seorang kepala sekolah (Hanifah, 2015)

Dengan adanya pola kepemimpinan yang tendensi pada pola kepemimpinan yang mengayomi, kepala sekolah adalah sosok yang religius dan sungguh-sungguh dalam menjalankankan agamanya, kepala sekolah memahami bahwa sumber dari energi kepemimpinan harus berasal dari pemilik otoritas tertinggi yaitu Allah sendiri (Wijaya, 2019) dalam hal ini, kepala sekolah beragama Kristen sebagai objek untuk melihat gaya kepemimpinan yang secara automatis melekat pengaruh ajaran agama pada setiap keputusan dan wibawa yang tertampilkan dalam hubungannya dengan orang lain, pada awalnya tidak ada perbedaan mendasar dengan kepala sekolah-kepala sekolah lain halnya seorang tenaga pendidik yang diberikan tugas untuk memimpin suatu sekolah dimana diselenggarakan proses belajar mengajar, ada keunikan dari seorang kepala sekolah yang memiliki latar belakang agama Kristen, sejalan berjalannya waktu, dalam perilaku kepala sekolah tersebut menggambarkan sebuah pribadi yang berada pada garis terdepan diwilayahnya, berupaya mengkoordinasikan dan meningkatkan performa pembelajaran yang mengarah pada suatu kualitas, diketahui bersama bahwa seorang kepala sekolah diangkat untuk menduduki jabatan serta harus bertanggung jawab penuh mengkoordinasikan upaya bersama mencapai tujuan pendidikan pada level sekolah yang dipimpinnya. kata beratanggung jawab penuh memiliki arti yang sangat mendasar tetapi dalam prakteknya, kepala sekolah menbutuhkan kerja sama dan kepedulian bersama sebagai satu-kesatuan, faktor pendukung lain yang diharapkan sinergitasnya yang perlu diperhitungkan seperti: guru, peserta didik, dan lingkungan yang mempengaruhi proses pembelajaran. Posisi kepala sekolah memiliki peran yang menggerakkan segala komponen sehingga mempengaruhi jalannya sistem yang ada dalam sekolah. kepala sekolah pasti mengenal setiap ataupun salah satu komponen pendidikan yang bisa dan mampu berperan dalam meningkatkan kualitas pendidikan, diatas semua itu kepala sekolah tetap menjadi penanggung jawab atas penyelenggaraan pendidikan, dengan 
kontrol ketat dan terarah pada bidang administrasi sekolah, pembinaan tenaga pendidikan, pendayagunaan serta pemeliharaan sarana dan prasarana dan tempat komponen-komponen lainnya semuanya dilakukan seperti tujuan semula berdasarkan kesepakatan bersama agar sekolah dapat mencapai tujuannya secara etektif dan efesien. Menjadi seorang kepala sekolah harus mempertimbangkan berbagai aspek sebab jabatan tersebut harus mampu melaksanakan fungsi-fungsi manajerial seperti perencanaan, pengorganisasian, pengarahan, pemberian motivasi, pelaksanaan, pengorganisasian pengendalian, evaluasi dan inovasi sehingga tidak bagitu saja mengangkat kepala sekolah karena beresiko terhadap kualitas pendidikan, berjalannya kepemimpinan seorang kepala sekolah dengan gaya kepemimpinannya pada akhirnya bermuara pada suatu tampilan pembelajaran, Jika pembelajaran di sekolah baik tentunya akan menghasilkan prestasi siswa dan nama baik sekolah yang dipimpinnya, dampak ini meperjelas bahwa kepala sekolah memilki peran langsung berkaitan dengan proses pembelajaran. sehingga wajar kadang kala keputusan yang dikeluarkan sering dianggap represif, padahal jika diamati lebih lagi ada tujuan tersirat yaitu terciptanya suatu kualitas dengan kontrol situasi dibawah koordinasi seorang yang memang disiapkan karena layak menjadi seorang leader atau pemimpin dengan demikian tidak diragukan mampu menciptakan kondisi-kondisi yang memungkinkan bagi lahirnya iklim kerja dan hubungan antar manusia yang harmonis dan kondusif. Dalam berjalannya pengamatan, peneliti mulai mengetahui satu perbedaan mendasar yang dibawah seorang kepala sekolah beragama Kristen dengan kepala sekolah lain. Konsep orang tua terasa kental, peneliti melihat norma-norma Alkitabiah yang di hidupkan dalam setiap tindakan kepemimpinan kepala sekolah tersebut. Dalam kitab suci Kristen jelas secara gamblang dikatakan dan dicontohkan oleh Tuhan Yesus sebagai pemimpin dan orang tua, mencerahkan, membimbing, membekali, mengayomi, memfasilitasi namun diatas itu semua ada kasih sebagai panglima tertinggi mendasari setiap tindakan tersebut. Demikian pula kepala sekolah beragama Kristen yang sudah mengenal Kristus mempraktekkan kasih dalam tindakan pengarahan, pembinaan dan lain-lain untuk mensejaterakan. posisi kepala sekokah seperti ayah atau orang tua yang menyayangi anak dengan kasih Philia sehingga berharap semua kebaikan turun dan dilimpahkan pada anak yang dikasihinya, begitu juga kepala sekolah beragama kristen yang sudah mengetahui kebenaran dan menghidupi firman yang Alkitabiah mengharapkan segala

19| Gaya Kepemimpinan Kepala Sekolah Beragama Kristen ..., Alki; Abai 
kebaikan dan kelimpahan menyertai seluruh bawahannya dan orang sekitarnya, sehingga memungkinkan menjadi pemimpin yang membawa kualitas atau mutu pada sekolah sesuai karakteristik sekolah tersebut. (Tambunan, 2020)

\section{Gaya Kepemimpinan Alkitabiah}

Gaya kepemimpinan dapat dikatakan sebagai indentitas dan citra bagaimana dan apa yang dilakukan pada saat seseorang sedang memimpin, apabila gaya kepemimpinan mampu mengendalikan organisasi atau bagian dari kepemimpinan dapat di perkirakan tujuan bersama akan tercapai. Objantoro (2019) berkata bahwa kepemimpinan adalah suatu proses upaya yang diharapkan dapat melibatkan sebuah tim kerja untuk mncapai tujuan bersama. Sebaliknya, jika dalam prakteknya, pemimpin tidak mampu mengendalikan organisasi dan terindikasi melemahkan tujuan bersama yang dicirikan kurangnya kepercayaan terhadap kepemimpinannya, di perkirakan terjadi Penyimpangan dari gaya kepemimpinan yang sebagaimana mestinya harus dilakukan. menurut iman Kristen. Norma-norma yang berlandaskan Alkitabiah pastilah suatu kesempurnaan dan bisa diimplementasikan dalam setiap bagian kehidupan. Untuk mempraktekkanya dalam substansi kepemimpinan, pastilah tidaklah sulit. Berdasarkan pengamatan dan pengumpulan data lainnya peneliti menarik suatu garis, bahwa seorang pemimpin dan dalam hal ini kepala sekolah yang beragama atau beriman Kristen bisa dan mampu menjalankan gaya kepemimpinan Alkitabiah, karena memang menghidupinya dalam perilaku dan perbuatan, standar gaya kepemimpinan Alkitabiah tidak seperti standar gaya kepemimpinan yang ditawarkan dunia. Pada karakter pemimpin diantaranya gaya kepemimpinan demokratis, gaya kepemimpinan otokratis atau otoriter, gaya kepemimpinan instruktif, gaya kepemimpinan delegatif, gaya kepemimpinan birokratis, gaya kepemimpinan partisifatif, gaya kepemimpinan konsultatif, dan gaya kepemimpinan situasional. Akan tetapi ditawarkan suatu gaya dan menjadi acuan yang menyerap semua dari kebaikan yang kompleks terdapat didalam nilai-nilainya yaitu gaya kepemimpinan Alkitabiah, gaya kepemimpinan ini menekankan dan di haruskan memegang dan mempraktekkan tuntunan buah roh dalam sendi-senidnya setiap ruang dari pola kepemimpinan seseorang (Galatia 5,22-23) "tetapi buah roh ialah kasih, suka cita, damai sejahtera, kesabaran, kemurahatian, kebaikan, kesetiaan, kelemahlembutan, 
penguasaan diri. tidak ada hukum yang menentang hal-hal itu." dalam hal ini Djadi (2009) menyarankan bahwa untuk menjadi seorang pemimpin yang baik dan efektif haruslah memiliki karakter yang baik.

Gaya kepemimpinan seseorang pastilah tidak dibentuk tanpa menyesuaikan dengan situasi dan kondisi yang dialami, pada konsepnya gaya kepemimpinan dapat dikatakan sebagai prioritas dan diutamakan berjalan disetiap diri manusia ketika mengemban tugas sebagai pemimpin. Memang didalam diri setiap orang pasti memilki keterbatasan sehingga satu dengan yang lain bisa saja berbeda tindakan dan gaya penanganan ketika ada suatu masalah. Dan kebutuhan dalam pembentukan karakter kepemimpinan tersebut, kepemimpinan dicirikan sebagai cara atau sikap yang muncul pada setiao individual sehingga tercermin pola untuk mempengaruhi suatu individu kepada individu lain melalaui suatu interaksi. Seorang pemimpin memiliki cara serta ciri tersendiri dalam proses kepemimpinan mereka di sebuah organisasi, maka dari itu gaya kepemimpinan sangat mempengaruhi proses kegiatan, tujuan, serta output dalam organisasi tersebut.

\section{Agama Kristen Bukan Sekedar Identitas Tetapi Prioritas}

Lahirnya tata aturan penegasan dari identitas kehidupan sosial manusia secara universal dalam konsep ini dijelaskan bahwa manusia memilki caranya sendiri untuk mencari kebenaran yang hakiki, tuntunan agama dikaitkan dengan bahwa anugerah sehat secara emosional bersifat lunak, terbuka, toleran dan bersedia berubah adalah buah atau hasil tuntunan kehidupan dalam beragama, serta hadirnya agama diharapkan sebagai petunjuk hidup yang sarat dngan nilai-nilai moral ( Kasuwi, 2006).

Dewasa ini, kata beragama banyak mengalami pergeseran maka yang signifikan, semestinya agama dipahami sebagai wadah atau tempat memperbaiki kehidupan diri sediri dan jikalau semangkin sempurna juga harus berdampak kepada orang lain dan lingkungan, pemahaman sempit akan keberadaan agama bisa mengakibatkan tindakan yang patal dalam kehidupan dan erat kaitanya dengan keberlangsungan kondusifitas yang bercirikan akan rasa damai, tentram, suka cita, bebas dan terarah dalam aktifitas sosial di komunitas atau masyarakat. memilih seseorang pemimpin dalam hal ini pemimpin disekolah, bukan hanya berdasarkan kemampuan manajerial semata saja, tetapi juga mempertimbangkan aspek ketaatan pada aturan, seorang yang beragama dan

21 | Gaya Kepemimpinan Kepala Sekolah Beragama Kristen ..., Alki; Abai

Jurnal Christian Humanioran | http://e-journal.iakntarutung.ac.id/index.php/humaniora 
menjalankan segala arahan atau tuntunan agamanya dengan taat, sudah dapat dipastikan mampu mengemban amanat menjadi seorang pemimpin yang adil dan bijaksana, secara pendekatan logika, seseorang yang mampu dan terbiasa melakukan hal positif pada sisi yang lain, pasti mampu juga melakukan seperti norma-norma yang dipraktekkan disisi yang lain juga,dapat diketahui bersama bahwa agama sudah menemani banyak pemimpin baik lokal /nasional maupun dunia, dicitrakan agama adalah penuntun arah dan penyeimbang dalam kebijaksanaan mereka. dalam penelitian ini, peneliti menangkap suatu fenomena bahwa pemimpin pada suatu sekolah yang diteliti, mengabdikan dirinya pada bangsa dan negara dengan segenap hati, tidak melanggar undang-undang dan kebhinekaan, tidak menggaggu hak orang lain, tidak mengganggu keyakinan orang lain, bahkan menghargainya. dari pengamatan tersebut peneliti menarik makna bahwa identitas pemimpin beragama Kristren ternyata bukan terlabel dari ketaatan semu yang seremonial, tetapi citra dan identitas agama Kristen yang dianut, tercermin dari ketaatan akan aturan pemerintah dan naluri hidup bersama dengan damai dengan sesama manusia, baik langsung maupun tidak langsung sudah mencitrakan diriya sebagai pengikut Tuhan Yesus dan mencitrakan Kekeristenan yang bermakna positif, sebagai seorang yang amanat akan amanat agung, setiap diri manusia harus memprioritaskan amanat agung tersebut dalam dunia yang panah dan sementara ini, kepala sekolah memahami bahwa amanat berupa jabatan memiliki makna dan maksud tertentu dari yang maha kuasa, maksudnya jabatan yang dipercayakan tersebut memberikan penjelasan secara tersirat tentang Pribadi Tuhan Yesus dan keselamatan yang diberikannya, jika jabatan dilakukan dengan gaya kepemimpinan Alkitabiah yang menghidupi buah, buah roh dalam diri seorang pemimpin. berlandaskan sejarah apakah yang dipikirkan kepala sekolah tersebut, memiliki energi yang sama dengan sebagian para misionaris yang menginjili wilayah nusantara dengan pendekatan pendidikan dan kesehatan, memperkenalkan keselamatan kepada siapapun melalui tampilan perilaku sebagai teladan. mempertahankan iman dan memperkenalkan segala kebaikannya. dalam pekerjaan, bersama-sama dalam satu komunitas walapun memilki perbedaan suku, agama, ras dan adat istiadat dalam konsep kebhinekaan adalah berkat dan ciri khas kebersamaaan sebagai saudara setanah air yang patut dan harus disyukuri dari diri setiap 
pribadi anak bangsa generasi lepas generasi, bekerja baik dipemerintahaan dan swasta, pastilah mengalami kondisi tersebut, dalam penelitian ini, kepala sekolah yang bertugas di sekolah sekuler yang notabene memiliki keragaman, mensyukurinya sebagai anugerah dan selalu berprinsif untuk berlaku adil dan profesional mengedepankan kualitas yang diupayakan bersama dengan gotong-royong, demokratis dan partisipatif, jika berpedoman akan hal tersebut sehingga pada akhirnya akan muncul calon pemimpinpemimpin lain yang berkarakter dan berkualitas sama seperti Kristus (Tambunan, 2018).

\section{KESIMPULAN DAN SARAN}

Dalam tulisan ini, tergambar bagaimana gaya kepemipinan seorang kepala sekolah nasrani atau Penganut Agama Kristen di sekolah sekuler yang penuh keragaman, memberikan bukti sebagai kepemimpinan yang demokratis dimana tindakan kepemimpinan kepala sekolah dilakukan dengan prinsif -prinsif keadilan dalam bingkai kebhinekaan yang menjunjung tinggi kemajemukan. gaya kepemimpinan tersebut akan terlihat keunikannya jika kepala sekolah tersebut benar-benar meghidupi ajaran yang dianutnya, dampingan buah roh, akan menyertai kepemimpinan tersebut, sehingga mebentuk suatu gaya kepemimpinan Alkitabiah, kepala sekolah berjalan sesuai dengan hikmat dari pada Tuhan, sehingga identitas kekristenan tidak perlu diperdengarkan, tetapi tercitrakan melalui kepribadian yang menghidupi firman, dan amanat agung yang Tuhan inginkan untuk disampaikankan terungkap walaupun dengan pendekatan pendidikan. Dalam kesempatan ini peneliti memberikan saran kepada kepala sekolah pendidikan kristen kiranya selalu menjadi garam dan terang ditempat kerja, dan untuk peneliti yang ingin mengambil tema yang sama, diharapkan jangan ragu mengggali secara mendalam walaupun terkait SARA, akan tetapi dalam tuntunan kaidah-kaidah yang beralaku.

\section{UCAPAN TERIMAKASIH}

Penulis mengucapkan terima kasih kepada Bapak/lbu pengelola jurnal yang memberikan kesempatan artikel penelitian ini publish pada jurnal ini, serta tidak lupa penulis mengucapkan terima kasih juga pada semua pihak yang mendukung, kiranya Tuhan Yesus memberkati. 


\section{DAFTAR PUSTAKA}

Djadi, J. (2009) “ Kepemimpinan Kristen yang efektif” Jurnal Jaffray, Vol. 7 (1)

Hanifah, N. (2015) “ Pengaruh Lingkungan Kerja, Kepemimpinan dan Motivasi Kerja terhadap Kinerja Kepala Sekolah Dasar” Jurnal Ilmu Pendidikan UM, Jil. 21(2).

Kasuwi ( 2006) “Upaya Meningkatkan Kualitas Pendidikan Agama di Perguruan Tinggi Umum” Jurnal Ilmu Pendidikan UM, Jil. 13(2).

Murdiono, M. (2014) “ Pendidikan Kewargangaraan untuk Membangun Wawasan Global Warga Negara Muda" Jurnal Cakrawala Pendidikan, XXXIII. No. 3.

Objantoro, E. (2019) Kepmimpinan Multi Staff dalam Gereja Lokal” Intgritas: Jurnal Teologi STT Jakarta, Vol.1 (2).

Raharjo jati, W. (2014) "Toleransi Beragama dalam Pendidikan Multikulturalisme Siswa SMA Khatolik Sang Timur Yogyakarta" Jurnal Cakrawala Pendidikan, XXXIII. No.1

Tambunan, F. (2018) “ Karakter Kepemimpinan Kristen Sebagai Jawaban Terhadap Krisis Kepemimpinan Masa Kini” Vol. 1(1)

Tambunan, A. M. (2020). Strategi SMP Terbuka Dalam Meningkatkan Mutu.

Usat, Y. (2019) “ Kepemimpinan Blusukan : Model Kepemimpinan Kristen yang Membumi” Integritas: Jurnal Teologi STT Jakarta, Vol.1 (2) hal. 93-100

Virgo, \& Slameto (2018) “Evaluasi Program Manajerial Kepala Sekolah” Jurnal Kelola UKSW, Vol. 5(2).

Wijaya, H. (2019) “ Kepemimpinan Para Rasul dan Relvansinya bagi Pemimpin Gereja di Era Revolusi Industri 4.0” Integritas: Jurnal Teologi STT Jakarta, Vol.1 (2). 